\title{
HSPG2 wt Allele
}

National Cancer Institute

\section{Source}

National Cancer Institute. HSPG2 wt Allele. NCI Thesaurus. Code C95447.

Human HSPG2 wild-type allele is located within 1p36.1-p34 and is approximately $115 \mathrm{~kb}$ in length. This allele, which encodes basement membrane-specific heparan sulfate proteoglycan core protein, plays a role in both the structure of and cell interaction with the basement membrane. Mutation of the gene is associated with both Schwartz-Jampel syndrome and Silverman-Handmaker type dyssegmental dysplasia. 